vol.3 No.1 ISSN:18235-2016

\title{
KNOWLEDGE OF UNIVERSITY FEMALE REGARDING SEXUAL HEALTH EDUCATION AT MANSOURA UNIVERSITY
}

\author{
Hayam A. EL-Refai* Amel I. Ahmed* and, Samar E. Abd-Elraouf \\ Community Health Nursing Department, Faculty of Nursing, Mansoura University, Egypt* \\ Email of corresponding author: Refai.haya@yahoo.com
}

\begin{abstract}
:
Background: Adolescence is a crucial phase of life and encompasses a nice result on the adolescent period. It's a time once teenagers develop the information, attitudes and skills that facilitate them to become sexually healthy. Aim of the study: this study aimed to assess University females' knowledge regarding sexual health education. Method: Descriptive study was conducted among (585) adolescent girls registered at Mansoura university at the first, second and third years with, Mansoura University, Egypt. Data were collected using three tools; the first tool was a structured questionnaire which included socio-demographic data, second tool was self-administered questionnaire to assess university females' knowledge and cultural preferences, third tool was attitude scale to assess university females' attitude, the fourth tool was self- administered questionnaire to assess university female sexual health education methods and preferences. The study was conducted from August 2013to February 2014. Results: The mean age of the adolescent girls was $19 \pm 0.66$ years; about three fourths were belonging to middle social class. The participants showed poor score level of knowledge in relation to definition and changes of maturation, wet dreams, masturbation, abnormal sexual behavior, sexual transmitted disease. The main sources of knowledge were friends, families, mass media and internet. Conclusion: The main conclusion drawn from the current study is that the majority of the adolescent girls had poor score level of knowledge regarding sex education. Recommendations: It was recommended to apply professional, comprehensive and individualized sex education focusing on improving the knowledge and increasing awareness of adolescent girls to improve their sexual health and prevent potential sexual transmitted diseases.
\end{abstract}

Key Words: Adolescent girls- Knowledge -Sex - Education.

\section{Introduction:}

Adolescence is a crucial adulthood; it is marked period of human life that includes a by rapid physical, physiological great impact on the adolescent and psychological changes. This future Mahan, et al. period is characterized by sexual,

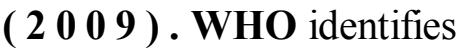
adolescence as the period in human growth and development that psychological and behavioral maturation WHO, (2013). It represents one among happens after childhood and before all the important transitions through 
Hayam A. EL-Refai et. al.

\begin{tabular}{lllll}
\hline the generation. & Adolescents & Nations & Population & Division, \\
represent the well-being of a & (2013).
\end{tabular}
society, its development and good health helps to ensure independence, security, and productivity across the life course Cromer, (2013).

Adolescents comprise the 1019 year-old age group and youth the 15-24 year old age group UNICEF, (2012). Globally, the number of young people between ages 10 and 24 is at an all-time high of more than 1.8 billion. Over 90 percent of those live in developing countries, where people under the age of 25 make up as much as 47 percent of the population.

Approximately half of them (900 million) are adolescent girls and young women UNICEF, (2010).

In Egypt, one in five people is between the ages of fifteen and twenty four, a total of sixteen million in 2012, in line with the United Nations Population Division, in the next fifteen years, more than quite twenty six million Egyptians can reach age of fifteen. Female percentage in Egypt was measured $49.78 \%$ in 2013. Preparing these adolescent girls for the transition to adulthood, a time once sex and relationships are central, could be a challenge for sexual health educators United

Sexuality is the values, attitudes, feelings, interactions and behaviors. Sex is emotional, social, cultural, and physical aspects of life. Sexual development is a part of sex, and it begins earlier in life than pubescence National Child Traumatic Stress Network (2009), and, Basavanthappa (2011).

Currently, adolescent girls acquire very little or no correct data relating to sex that enable them to force against sexual abuse, sexually transmitted infections, as well as HIV Alexandra, Lipi, (2008). Adolescents would need correct and comprehensive education regarding sex to follow healthy sexual behavior as adults. Russell, (2005 A,B) Welles, (2005). Contributing to this negativity about sex education there is a need for positive conceptualizations of female sexuality and pleasure within sexual education practices Fields \& Tolman, (2006); Tolman, Hirschman, \& Impett, (2005).

Sexual health education could be a lifelong process of acquiring data and forming attitudes, beliefs, and values concerning such vital topics as identity, relationships, and intimacy. Early sexual health education for adolescent girls is important because even though 
most teens are not cognitively or emotionally ready to have children, they are biologically and physically prepared Shedlin et al., (2013) \& Douglas, (2007). The Sexuality Information and Education Council of the United States (SIECUS) believes that every one has the right to comprehensive sex education that addresses the socio-cultural, biological, psychological, and religious dimensions of sex by providing information; exploring feelings, values, and attitudes; and developing communication, decision-making, and criticalthinking skills SIECUS, (2009)

The sexual health education were designed to provide information regarding human development and reproduction, to form adolescent girls' realization of all sorts of sexual issues, and to push adolescent girls' respect and appreciation of themselves, their families and others. Sexual health education would reduce immature maternity and birth; explain necessary topics like pubescence, sexual health and reproductive systems Kuriansky \& Schroeder (2009).

Hence assessing the knowledge of university females is vitally important in achieving sexual health education goal at the knowledge level. Therefore, the main objective of this study was to assess university females' knowledge about sexual health education and sexuality.

Material and Methods:

\section{Research design:}

The design used in this study was cross sectional design.

\section{Setting}

This study was conducted in 15 faculties (all theoretical and practical faculties) in Mansoura University from August 2013 to February 2014, in which subjects represent the rural and urban community.

\section{Subjects and sampling:}

\section{Subjects:}

Female students registered at Mansoura University at the first, second and third years.

\section{Sampling:}

\section{Sample size:}

The required sample size included in the descriptive study was 585 of adolescent girls, when $\alpha=5 \%$, Population size $=23190$ students girls registered at Mansoura University from first, second and third academic years, desired precision $=\quad 4 \%, \quad$ expected prevalence of correct knowledge and beliefs about sexual health among adolescent girls $=50 \%$ and design effect $=1$ (Wayne\& Danial, 1987). 
Hayam A. EL-Refai et. al.

\section{Study tools}

There are three tools used in the study:

\section{Tool I: A structured questionnaire included two parts:}

- Part 1: the first part included adolescent girls' personal data such as: age, residence, faculty, and grade.

-Part 2: the second part was social level assessment by using scale of Fahmi and El-Sherbini after modification for "Socio-demographic data" (Fahmy, \& EL Sherbiny, 1983).

Box (II): Socio-economic level

\begin{tabular}{|l|c|}
\hline $\begin{array}{c}\text { Socio- } \\
\text { economic level }\end{array}$ & Percentile \\
\hline Very low & $0-19$ \\
\hline Low & -24 \\
\hline Middle & -30 \\
\hline High levels & $31-37$ \\
\hline
\end{tabular}

Tool II: self-administered questionnaire of Knowledge assessment

The self-administrated questionnaire assess adolescent girls' knowledge about sexuality, and sexual health including sexual development stages, wet dream, menstruation, homo and hetero sexualities, and sexual transmitted diseases.

It was classified into 6 categories; all of these categories composed of 72 questions. One mark awarded for each correct answer as following:

1. Definition and anatomy of reproductive system and maturation changes $\theta$ (It includes 26 items $=26$ marks).

2. Definition of sex, sexual need and safe sexual relation (It includes 14 items $=14$ marks).

3. Wet dreams and masturbation (It includes 15 items $=15$ marks)

4. Abnormal sexual behavior (It includes 12 items $=12$ marks) and Homosexuality (It includes 14 items $=14$ marks).

5. STDs, Gonorrhea, Syphilis and Hepatitis (It includes 60 items $=60$ marks).

6. Adolescent care (It includes 12 items $=12$ marks).

The total scores of the knowledge ranged from 0 to 164. The knowledge level was categorized into three categories as:

- Poor $=$ scores less than $50 \%$ of total scores (0 - less than 82).

- Fair $=$ scores $50 \%$ to less than $75 \%$ of total sores (82 - less than 123).

- Good $=$ scores $75 \%$ of total scores (123-164). 
KNOWLEDGE OF UNIVERSITY FEMALE REGARDING etc....

\section{Tool III: $\quad$ Self-administered questionnaire sheet of adolescent girls' cultural and preference questionnaire sheet}

This questionnaire was containing the following parts:

- Part 1: It assessed adolescent girls' cultural background regarding sexuality, sexual health and sexual health education, including for example; (values, beliefs, traditions, religious and/or spiritual beliefs and practices, sources of information).

- Part 2: It explored adolescent girls' preferences in relation to sex education including for example the different aspects of content, teaching and learning methods.

This tool was classified into 2 categories, these categories composed of 26 questions. One mark awarded for each (positive response) answer as the following:

1. Cultural background regarding sexuality, sexual health and sexual health education (It includes 44 items $=44$ marks).

2. Preferences in relation to sex education (It includes 15 items $=15$ marks).
Tool IV: Adolescent girls' attitude scale Likert, (1932):

This scale composed of 32 questions to assess adolescent girls' attitudes regarding sexuality, sexual health and sexual health education.

One mark awarded for each (positive response) as the following: (It includes 120 items $=$ 120 marks)

The total scores of the attitude ranged from 0 to 120 , one point for each positive attitude.

The attitude was categorized into negative and positive.

- positive $=$ scores more than $50 \%$ of total scores $(60-120)$.

- Negative $=$ scores less than $50 \%$ of total sores ( 0 - less than 60$)$.

\section{$\mathrm{V}$ :Self-administered questionnaire sheet of health education methods and preference of adolescent girls}

Self administrated questionnaire was used to explore the adolescent girls' preferences in relation to health education topic and teaching methods Javadnoori1, et- al, (2012) \& Padhy, et al., (2013). It included 5 categories; all of these categories were composed of 38 questions as the following:

1) Definition, importance, suitable age of sex education (It included 14 items). 
2) Preferred subjects, persons, and places for sex education (It included 12 items).

3) Teaching methods and teaching media (It included 12 items).

4) Clusters that are in need for sexual health education (It included 4 items).

\section{Methods}

- An official letter from the faculty of nursing was submitted to obtain approval to conduct the study.

- An official letter from the faculty of nursing developed to the appropriate authorities in the selected settings in Mansoura university to obtain permission for conducting the study after explanation the aim of the study determine the starting time of the study and explain the study process to gain their cooperation and support during data collection.

- Adolescent girls were informed of the aim of the study and were assured that their identities and responses to the interview would be confidential. They need the right to participate or not in the study and that they can withdraw at any time without any reason.

- Verbal consent was obtained from adolescent girls to participate in the study.
Development of the study tools

- Tools were developed by the researcher after reviewing the related literature.

- A jury involves five experts in the field of community health nursing and statistics tested validity of the developed tools, and the required modifications were carried out.

\section{Pilot study}

- A Pilot study was conducted on $10 \%$ of the studied sample (59 adolescent girls) who were selected randomly from the same settings and not included in the study to evaluate the clarity, applicability and reliability of the research tools, estimate the approximate time required for data collection, identify the possible obstacles or problems that may hinder data collection and overcome measures.

- On the basis of collected information; the necessary modifications were done, some questions were added and others were clarified or omitted. Each interview consumed about (3035 minutes) to be filled.

- The duration needed for each participant to fill the questionnaire ranged from 25-30 minutes, and the filled 
questionnaire /day were about 710 questionnaires.

- For purpose of quality control, the questionnaires were checked for completeness after each day by the researcher.

- Data generated for the study was analyzed using Statistical Package for Social Sciences (SPSS version 20). Statistical techniques employed include descriptive statistics (frequency, percentage and arithmetic mean \pm standard deviation).

\section{RESULTS}

\section{Demographic characteristics of adolescent girls}

Distributions of adolescent girls according to their socio-demographic characteristics are presented at Table (1). Results revealed that the mean age of the adolescent girls is $19 \pm 0.66$ years. The majority is $(74 \%)$ of the adolescent girls belong to middle social class.

\section{Knowledge of adolescent girls}

Generally, tables 3\& 4 revealed that poor score level of knowledge among adolescent girls about $\quad 68.4 \% \quad$ regarding reproductive system anatomy and about $90.4 \%$ regarding maturation changes. Only $0.5 \%$ of adolescent girls mentioned the meaning of maturation, and $2.6 \%$ of them stated changes of reproductive system.

With respect to abnormal sexual behaviors; table (5) showed that $95.9 \%$ of them showed poor knowledge score level. Moreover, $85.6 \%$ of the adolescent girls showed poor knowledge about wet dreams and masturbation. Concerning sexual transmitted diseases, results represented that only $2.3 \%$ of the adolescent girls knew the different types of STDs. The result revealed that more than four fifth $(88.9 \%)$ of the adolescent girls have poor score of knowledge about AIDS, syphilis and gonorrhea. More than half the adolescents ever heard about AIDS respectively. While regarding the knowledge of adolescent girls about hepatitis more than one fourth $(30.6 \%)$ showed poor knowledge score level (Table 5).

Results presented in table (5) illustrated poor score $98.7 \%$ compared to good score $0.7 \%$ level of knowledge regarding to sexual health a mean score of $1.44 \pm 0.76$ points in relation to Reproductive system and maturation, sexual need and safe sexual desire, wet dreams and masturbation, abnormal sexual behavior, sexual transmitted disease as $\mathrm{AID}_{\mathrm{S}}$, hepatitis, gonorrhea, syphilis and adolescent care.

In relation to distribution of adolescent girls according to 
Hayam A. EL-Refai et. al.

their correct knowledge about adolescent care and practice to improve sexual health. Table (6) showed that, more than two fifth $(41.4 \%)$ of adolescent girls showed positive practices that improve sexual health, while less than three fourths $(73.2 \%)$ have negative practices to improve sexual health.

In relation to premarital services, $61.2 \%$ of adolescent girls showed poor knowledge score level. Moreover, 26.5\%, 29.1\% and 7.4\% of them identified medical check-up services, counseling services and health education respectively with a mean score of $0.44 \pm 0.63$ points.

Table (7) showed that, more than half of the participants considered their friends/ relatives/ neighbors were the main source of knowledge which represented $60.9 \%$ followed by the magazines $26.3 \%$. However, the internet was mentioned by $18.1 \%$ of the participants respectively.

Table (8) represented that, less than half $(47.5 \%)$ defined sexual health education as providing information about sexual relation, they named it, marital education. While more than three thirds have no information about sexual health education

In relation to time to start sexual health education, $98.3 \%$ of adolescent girls want to start sexual health education prepuberty. Moreover, large proportion of them preferred maturation changes and safe sexual relation as subjects of sexual health education.

Regarding preferred person education, Table (9) showed that 93.5\% of adolescent girls preferred friends, parents, and female doctors. However, only $14.2 \%$ of adolescent girls preferred internet for sexual health education.

In relation to preferred places for sexual health education, $82.1 \%$ of adolescent girls prefered private clinics and homes for sexual health education. However, only (19.6/5) of adolescent girls prefer mosques, churches and special centers for sexual health education.

Concerning preferred method used for sex education, the most of adolescent girls (92\%) prefers peer sexual health education, lectures and open discussion, while $0.3 \%$ of them prefered watching films for sexual health education.

In relation to relation between knowledge and attitude of adolescent girls, Table 10 showed that the most of adolescent girls have poor knowledge with negative attitude about sexual health education. Only $0.9 \%$ of them reported positive attitude regarding sexual health education 


\section{Results:}

Table (1) Adolescent girls' distribution according to socio-demographic characteristics

\begin{tabular}{|c|c|c|}
\hline Items & $\mathrm{N}=585$ & $\%$ \\
\hline Age/ years & & \\
\hline 19- & 452 & 77.3 \\
\hline $20-$ & 70 & 12.0 \\
\hline 21 & 63 & 10.8 \\
\hline Mean \pm SD & \multicolumn{2}{|c|}{$19 \pm 0.66$} \\
\hline \multicolumn{3}{|l|}{ Residence } \\
\hline Rural & 503 & 86.0 \\
\hline Urban & 82 & 14.0 \\
\hline \multicolumn{3}{|l|}{ Adolescent girl's social level } \\
\hline High social level & 98 & 16.8 \\
\hline Middle social level & 433 & 74 \\
\hline Law social level & 54 & 9.2 \\
\hline${ }^{\mathrm{x}} \pm \mathrm{SD}$ & \multicolumn{2}{|c|}{$2.57 \pm 0.76$} \\
\hline
\end{tabular}

Table (2): Adolescent girls knowledge level about reproductive system and maturation.

\begin{tabular}{|c|c|c|c|c|c|c|c|}
\hline \multirow{2}{*}{ Items } & \multicolumn{2}{|c|}{ Poor } & \multicolumn{2}{|c|}{ Fair } & \multicolumn{2}{|c|}{ Good } & \multirow{2}{*}{$\begin{array}{c}\text { Mean } \\
\pm \text { SD }\end{array}$} \\
\hline & No & $\%$ & No & $\%$ & No & $\%$ & \\
\hline $\begin{array}{l}\text { Anatomy of female reproductive system } \\
(\text { Scores =4) }\end{array}$ & 400 & 68.4 & 81 & 13.8 & $\begin{array}{c}10 \\
4\end{array}$ & 17.8 & $1.04 \pm 0.56$ \\
\hline $\begin{array}{l}\text { Anatomy of male reproductive system } \\
(\text { Scores }=4)\end{array}$ & 404 & 69.1 & 176 & 30.1 & 5 & 0.9 & $0.7 \pm 0.47$ \\
\hline \multicolumn{8}{|l|}{ Maturation } \\
\hline Female maturation(Scores $=9$ ) & 538 & 92 & 32 & 5.5 & 15 & 2.6 & $2.74 \pm 1.33$ \\
\hline Male maturation(Scores $=9$ ) & 550 & 94.2 & 24 & 4.1 & 11 & 1.7 & $2.31 \pm 1.38$ \\
\hline Total knowledge score $($ Scores $=26)$ & 529 & 90.4 & 53 & 9.1 & 3 & 0.5 & $1.1 \pm 0.3$ \\
\hline
\end{tabular}


Hayam A. EL-Refai et. al.

Table(3) Distribution of adolescent girls according to their knowledge about wet dreams and masturbation

\begin{tabular}{|c|c|c|}
\hline Items & $\mathrm{N}=\mathbf{5 8 5}$ & $\%$ \\
\hline \multicolumn{3}{|l|}{ Correct knowledge } \\
\hline \multicolumn{3}{|l|}{ Definition of wet dreams* } \\
\hline Dreams with loved person & 97 & 16.6 \\
\hline Orgasm involving either ejaculation throughout sleep & 6 & 1 \\
\hline \multicolumn{3}{|l|}{ Wet dreams occur to } \\
\hline Male and female & 231 & 39.5 \\
\hline \multicolumn{3}{|l|}{ Definition of masturbation* } \\
\hline Abnormal personality & 84 & 14.4 \\
\hline Erotic stimulation especially of one's own genital organs resulting in orgasm & 7 & 1.2 \\
\hline \multicolumn{3}{|l|}{ Causes to practice masturbation* } \\
\hline Overcoming sexual need & 82 & 14.3 \\
\hline Abnormal personality & 247 & 42.2 \\
\hline Production of 'endorphin' hormone & 3 & 0.5 \\
\hline \multicolumn{3}{|l|}{ Harms of masturbation* } \\
\hline Sexual weakness & 443 & 75.7 \\
\hline Orgasm problem & 42 & 7.2 \\
\hline Obsessive compulsive disorder of masturbation & 14 & 2.4 \\
\hline \multicolumn{3}{|l|}{ In correct knowledge } \\
\hline \multicolumn{3}{|l|}{ Definition of wet dreams } \\
\hline Abnormal personality & 97 & 16.6 \\
\hline Love and social relation & 35 & 6 \\
\hline \multicolumn{3}{|l|}{ Wet dreams occur to } \\
\hline Male only & 76 & 13.0 \\
\hline Female only & 60 & 10.3 \\
\hline \multicolumn{3}{|l|}{ Definition of masturbation* } \\
\hline Secrete sex practice & 120 & 20.5 \\
\hline Psychological disorder & 84 & 14.4 \\
\hline \multicolumn{3}{|l|}{ Causes to practice masturbation } \\
\hline Physiological changes & 62 & 10.6 \\
\hline \multicolumn{3}{|l|}{ Harms of masturbation* } \\
\hline Life threatening disease as cancer & 35 & 6 \\
\hline Madness & 53 & 9.1 \\
\hline Knee pain & 92 & 15.7 \\
\hline
\end{tabular}


Table(4): Distribution of adolescent girls according to their knowledge concerning abnormal sexual behaviors.

\begin{tabular}{|c|c|c|}
\hline Items & $\mathrm{N}=\mathbf{5 8 5}$ & $\%$ \\
\hline \multicolumn{3}{|l|}{ Definition of abnormal sexual behavior* } \\
\hline $\begin{array}{l}\text { person's sexual arousal and gratification depend upon } \\
\text { fantasizing regarding and engaging in sexual behavior that is } \\
\text { atypical and extreme }\end{array}$ & 9 & 1.5 \\
\hline $\begin{array}{l}\text { Romantic attraction, sexual attraction } \\
\text { between members of an equivalent sex or gender }\end{array}$ & 8 & 1.4 \\
\hline \multicolumn{3}{|l|}{ Causes of abnormal sexual behavior } \\
\hline Abnormal personality & 396 & 67.7 \\
\hline Diseases, as(brain lesion, an endocrinal abnormality) & 124 & 21.2 \\
\hline \multicolumn{3}{|l|}{ Types of abnormal sexual behavior* } \\
\hline Homo sexuality (Female with female/ Male with male) & 11 & 2.1 \\
\hline Oral or anal sex & 52 & 9.1 \\
\hline Sex with animals ( zoophilia) & 2 & 0.3 \\
\hline \multicolumn{3}{|l|}{ Harms of abnormal sexual behavior* } \\
\hline Sexual transmitted diseases & 257 & 43.9 \\
\hline Sexual dysfunction & 146 & 25.0 \\
\hline Psychological disorders & 189 & 32.3 \\
\hline
\end{tabular}

* More than one answers given.

Table( 5): Adolescent girls knowledge score about sexual health.

\begin{tabular}{|c|c|c|c|c|c|c|}
\hline \multirow[t]{2}{*}{ Items } & \multicolumn{2}{|c|}{ Poor } & \multicolumn{2}{|c|}{ Fair } & \multicolumn{2}{|c|}{ Good } \\
\hline & No & $\%$ & No & $\%$ & No & $\%$ \\
\hline $\begin{array}{l}\text { Reproductive system and maturation } \\
\text { (Scores }=\mathbf{2 6}\end{array}$ & 529 & 90.4 & 53 & 9.1 & 3 & 0.5 \\
\hline $\begin{array}{l}\text { Sexual need and safe sexual desire } \\
(\text { Scores }=\mathbf{1 4})\end{array}$ & 501 & 85.6 & 39 & 6.7 & 45 & 7.7 \\
\hline $\begin{array}{l}\text { Wet dreams and masturbation } \\
(\text { Scores }=\mathbf{1 5})\end{array}$ & 501 & 85.6 & 73 & 12.5 & 11 & 1.9 \\
\hline $\begin{array}{l}\text { Abnormal sexual behavior } \\
\text { (Scores }=\mathbf{2 6} \text { ) }\end{array}$ & 561 & 95.9 & 16 & 2.7 & 8 & 1.4 \\
\hline $\mathrm{AID}_{\mathrm{S}}($ Scores $=15)$ & 535 & 91.5 & 40 & 6.8 & 10 & 1.7 \\
\hline Gonorrhea $($ Scores $=15)$ & 520 & 88.9 & 41 & 7 & 24 & 4.1 \\
\hline Syphilis $($ Scores $=15)$ & 575 & 98.2 & 5 & 0.9 & 5 & 0.9 \\
\hline Hepatitis $($ Scores $=\mathbf{1 5})$ & 179 & 30.6 & 118 & 20.2 & 288 & 49.2 \\
\hline Adolescent care $($ Scores $=\mathbf{2 3})$ & 360 & 61.5 & 205 & 35 & 20 & 3.4 \\
\hline $\begin{array}{l}\text { Total knowledge score (Scores }= \\
\text { 164) }\end{array}$ & 577 & 98.6 & 4 & 0.7 & 4 & 0.7 \\
\hline Mean \pm SD & & & & $=0.76$ & & \\
\hline
\end{tabular}


Hayam A. EL-Refai et. al.

Table(6 ): Distribution of adolescent girls according to their total knowledge Score about adolescent care and premarital service

\begin{tabular}{|c|c|c|}
\hline Items & $\mathbf{N}=\mathbf{5 8 5}$ & $\%$ \\
\hline \multicolumn{3}{|l|}{ Definition of adolescent care* } \\
\hline $\begin{array}{l}\text { Adequate and comprehensive services for adolescents } \\
\text { relevancy reproductive health services. }\end{array}$ & 27 & 4.6 \\
\hline $\begin{array}{l}\text { Optimal medical and reproductive health care, each } \\
\text { currently and within the future }\end{array}$ & 170 & 29.1 \\
\hline \multicolumn{3}{|l|}{ Improving sexual health } \\
\hline \multicolumn{3}{|l|}{ - $\quad$ Positive practices* } \\
\hline Maintaining Genital hygiene & 235 & 40.2 \\
\hline Taking healthy diet & 18 & 3.1 \\
\hline Practicing sport & 242 & 41.4 \\
\hline being in good psychological health & 19 & 3.2 \\
\hline Sleeping and walk up early & 132 & 22.6 \\
\hline Practicing morals as fasting & 35 & 5.8 \\
\hline Examining breast & 57 & 9.7 \\
\hline \multicolumn{3}{|l|}{ - $\quad$ Negative practices* } \\
\hline Avoiding STDS & 143 & 24.4 \\
\hline Avoiding sex with multi partner & 428 & 73.2 \\
\hline Avoid smoking and obesity & 120 & 20.5 \\
\hline Avoid alcohol & 18 & 3.1 \\
\hline \multicolumn{3}{|l|}{ Premarital sexual services* } \\
\hline Medical checkup & 155 & 26.5 \\
\hline Counseling & 170 & 29.1 \\
\hline Health education & 43 & 7.4 \\
\hline${ }^{x} \pm \mathrm{SD}$ & \multicolumn{2}{|c|}{$\frac{1}{0.44 \pm 0.63}$} \\
\hline
\end{tabular}

* More than one answers given. 
Table (7):- Distribution of the adolescent girls according to their Source of Knowledge regarding sexual health

\begin{tabular}{|l|r|r|}
\hline \multicolumn{1}{|c|}{ Items } & No(n=585) & \multicolumn{2}{c|}{$\%$} \\
\hline Source of knowledge about sexual health* & \multicolumn{2}{c|}{} \\
\hline Radio & 48 & 8.2 \\
\hline T.V. & 110 & 18.8 \\
\hline Net & 106 & 18.1 \\
\hline Magazines, news papers and books & 154 & 26.3 \\
\hline Family and neighbors & 196 & 33.5 \\
\hline Friends & 213 & 36.4 \\
\hline Schools and universities & 75 & 12 \\
\hline
\end{tabular}

* More than one answers given.

Table(8 )Distribution of adolescent girls according to their correct knowledge about sexual health education

\begin{tabular}{|c|c|c|}
\hline+2 & $\mathrm{~N}=\mathbf{5 8 5}$ & $\%$ \\
\hline \multicolumn{3}{|l|}{ Definition of sexual health education* } \\
\hline Information about sexual relation & 278 & 47.5 \\
\hline Sexual practice & 253 & 43.2 \\
\hline $\begin{array}{l}\text { Enable adolescents to acquire knowledge and skills in } \\
\text { managing responsible decisions }\end{array}$ & 28 & 4.8 \\
\hline \multicolumn{3}{|l|}{ Starting of sexual health education at* } \\
\hline - Pre-puberty & 575 & 98.3 \\
\hline - After puberty & 196 & 33.5 \\
\hline - Premarital & 185 & 31.6 \\
\hline - All stages & 80 & 13.7 \\
\hline \multicolumn{3}{|l|}{ Ending of sexual health education at } \\
\hline Not applicable at any age & 543 & 92.8 \\
\hline-45 & 28 & 4.8 \\
\hline$\geq 50$ & 14 & 2.4 \\
\hline Mean \pm SD & \multicolumn{2}{|c|}{ 3.35 \pm 12.07} \\
\hline \multicolumn{3}{|l|}{ Menstruation and it's physiological changes education at } \\
\hline-10 years & 116 & 19.8 \\
\hline-12 years & 270 & 46.2 \\
\hline$\geq 14$ years & 199 & 34 \\
\hline Mean \pm SD & \multicolumn{2}{|c|}{$0.63 \pm 0.88$} \\
\hline
\end{tabular}

* More than one answers given. 
Hayam A. EL-Refai et. al.

Table(9): Distribution of adolescent girls according to their values and preferences related to sexual health education.

\begin{tabular}{|c|c|c|}
\hline Items & $\begin{array}{c}\mathrm{No}(n=5 \\
85)\end{array}$ & $\%$ \\
\hline \multicolumn{3}{|l|}{ Preferred person to provide sexual health education* } \\
\hline Parent & 381 & 65.1 \\
\hline Friends & 547 & 93.5 \\
\hline Health educators & 363 & 62.1 \\
\hline Self learning & 231 & 39.5 \\
\hline \multicolumn{3}{|l|}{ Preferred places of sexual health education* } \\
\hline M.C.H. centers & 371 & 63.4 \\
\hline Private clinics & 480 & 82.1 \\
\hline Homes & 478 & 81.7 \\
\hline Churches and mosques & 113 & 19.3 \\
\hline Free centers for sexual health education to adolescent & 2 & .3 \\
\hline \multicolumn{3}{|l|}{ Preferred method/media used in sexual health education* } \\
\hline Lectures & 406 & 69.4 \\
\hline Group discussion & 343 & 58.6 \\
\hline Computer based learning & 278 & 47.5 \\
\hline Books & 110 & 18.8 \\
\hline Films & 2 & .3 \\
\hline \multicolumn{3}{|l|}{ Preferred sexual health education type* } \\
\hline Single & 305 & 52.1 \\
\hline In group & 280 & 47.9 \\
\hline Face to face & 307 & 52.5 \\
\hline \multicolumn{3}{|c|}{$\begin{array}{l}\text { Preferred subjects of sexual health education in adolescent } \\
\text { stage* }\end{array}$} \\
\hline Safe sexual relation & 122 & 20.9 \\
\hline Sexual health & 17 & 2.9 \\
\hline Sexual disease prevention & 8 & 1.4 \\
\hline Maturation changes & 40 & 6.9 \\
\hline
\end{tabular}

* More than one answers given.

Table(10): Relation between knowledge and attittude of adolescent girls related to sexual health education.

\begin{tabular}{|c|c|c|c|c|c|c|}
\hline \multirow{2}{*}{ Items } & \multicolumn{2}{|c|}{ Positive attitude } & \multicolumn{2}{|c|}{ Negative attitude } & \multirow[t]{2}{*}{$\mathbf{X}^{2}$} & \multirow{2}{*}{ P-Value } \\
\hline & No. & $\%$ & No. & $\%$ & & \\
\hline \multicolumn{7}{|c|}{ Knowledge of adolescent girls } \\
\hline Poor & 3 & 0.5 & 574 & 98.1 & $\begin{array}{c}23.6 \\
25\end{array}$ & $\begin{array}{c}<0.001 * \\
*\end{array}$ \\
\hline Fair & 2 & 0.3 & 2 & 0.3 & $\begin{array}{c}0.83 \\
6\end{array}$ & 0.67 \\
\hline Good & 1 & 0.1 & 3 & 0.5 & $\begin{array}{c}8.64 \\
5\end{array}$ & $<0.05^{*}$ \\
\hline
\end{tabular}

*Significant Difference

** Highly Significant Difference 
Discussion:

Sexual health is outlined

by the World Health

Organization (2006) not only as the absence of diseases or negative experiences relating to physiological property, though this is often a crucial side of the definition, however conjointly as the chance of getting enjoyable and safe sexual experiences Albarracín et al., (2007). Furthermore, the definition states that "the sexual rights of all persons should be revered, protected and fulfilled"

Bartholomew, et al., (2011).

Adolescents conferred a kind of unhappiness and discontent with SHE (sexual health education) inadequacy, separation, lack of educational materials, emphasizing on negative aspects of physiological property and superficiality. They perceived the shortage of sexual health connected information and skills of their lecturers, faculty counselors, and health care suppliers to handle their SHE needs, considerably in reference to psychological aspects of sexual health. Most of those critiques are conjointly rumored (more or less) by adolescent within the different studies across the world Douglas (2010) \& Oraby, (2013).

The findings of the current study illustrated that none of the adolescent girls had received any previous sexual health education concerning maturation, maturation changes, abnormal sexual behaviors, sexual transmitted diseases and adolescent care. These findings are in the same line with the results documented by Javadnoori1 et al., (2012) \& Roushdy, (2013).

As regarding to the level of knowledge, the current study showed poor score level of knowledge among the most of adolescent girls in relation to reproductive system and maturation changes. The poor knowledge level might be taken within the highlight of previous studies, that ended that insufficient formal education has impact on their poor score level of information. This interpretation might be confirmed by the finding of the current study that exposed that quite three fourths of the studied adolescent girls were low and middle social level. Social level can result in difficulties in obtaining information from illiterate folks, inability to buy books or magazines, and through media. They knew the maturation 
Hayam A. EL-Refai et. al.

\begin{tabular}{ll}
\hline $\begin{array}{l}\text { changes when first menstrual } \\
\text { period started (menarche), and } \\
\text { therefore the rumored mean age of }\end{array}$ & $\begin{array}{l}\text { large proportion of adolescents } \\
\text { weren't aware about sexually } \\
\text { transmitted diseases Forham, et }\end{array}$ \\
menarche was $13.48 \square \pm \square 1.69$ SD. & al., (2013), Shedlin, et al., (2013), \\
Similar results were conjointly & Samkange-Zeeb, F., Spallek, L., \\
reported by Kasiye, Frehiwot \& & Zeep, H., (2011), et al., (2011), \\
Getahun (2014), Stephen, Bryant & Kirby, Obasi \& Fonner, et al., \\
\& Wilson (2008), and, Wong et & $\begin{array}{l}\text { (2014), Sionean, et al., (2014), } \\
\text { Zajac, et al., (2014), John, et al., } \\
\text { al., (2013). }\end{array}$ \\
& $(\mathbf{2 0 1 4 ) .}$
\end{tabular}

Adolescent girls reported
poor level of knowledge
concerning abnormal sexual
behavior, autoeroticism and wet
dreams, the majority of them are in
great need to have information
about safer sexual behaviors,
factors affecting these needs
(Rathfisch, et al., 2012, Yin, et al., 2014, Patricia G., Eric R. Buhi,S., Dunsmore, M., 2006, Bearinger, et al., 2007). This finding was in agreement with the findings of the current study.

As regarding to the level of knowledge, the current study showed poor score level of knowledge among the majority of adolescent girls that associated with sexually transmitted diseases and AIDS, more than half of the adolescent girls never heard about AIDS respectively. Moreover, about three fourths of them had no information about AIDS in terms of mode of transmission and prevention. This finding was in agreement with findings expressed by similar studies, that reported a
The findings of this study indicated that most sources of information regarding sexual health, STDs and safer sex were friends, family, media, internet, books and magazines. Often adolescent girls were confused or misinformed due to incorrect information received from these sources. Moreover, half of the adolescent girls considered it was impossible to talk with their parents obout sex and STDs. However one fourth of them used their mothers as a source of information, nine percent of adolescent girls prefered female doctors as their knowledge supply. While some of them remarked that "I am a girl so I need to receive data about sexual health from most popular female doctor". Therefore evidence-based sexual health education ought to be a significant strategy in culturalbased sex education, with user friendly resources prepared to adolescent girls Alexandra \& Lipi (2008), Lal, Vasan \& Sarma (2000). 
The results of the current study showed that the most of the adolescent girls rumored negative attitude with poor knowledge toward sexual health, sexual health issues and sexual health education. Moreover they indicated that attitudes, norms and beliefs around sexual behavior determined the supposed sexual behavior of adolescent girls. This finding was in agreement with findings expressed by similar studies, that rumored that almost all of adolescent girls have negative attitude toward sexual health education Chang, (2014), Wang, (2013, Alexandra \& Lipi (2008), Shweta, Mundkur, Chaitanya (2011)

\section{References:}

1. Alexandra M., Lipi D., (2008): Study of knowledge, perception and attitude of adolescent girls towards STIs/HIV, safer sex and sex education: (A cross sectional survey of urban adolescent school girls in South Delhi, India) BMC Women's Health 2008, 8: 12

2. Albarracín, J., Albarracín, D., \& Durantini, M. (2007): Effects of HIV-prevention interventions for samples with higher and lower percents of Latinos and Latin Americans: A meta-analysis of change in condom use and knowledge. AIDS \& Behavior, AIDS. Behav. Jul; 12(4): 521-543.

3. Bartholomew , L. K. , Parcel , G. S. , Kok , G. , Gottlieb , N. H. , \& Fernández, M. E. ( 2011 ): Planning health promotion programs: An intervention mapping approach () , $3^{\text {rd }}$ ed. . San Francisco , CA : Jossey-Bass .

4. Basavanthappa, B., (2011): Essential Of Midwifery And Obstetrical Nursing, $1^{\text {st }}$ ed., Jay pee brothers, New Delhi, p.p. 87 .

5. Chang Y., (2014): Attitudes Toward Sexual Relationships And Premarital Sex: Implications For Promoting Sexual Health

6. Chimbiri, A. (2007): The condom is an "intruder" in marriage: Evidence from rural Malawi. Social Science \& Medicine, 64, 1102-1115.

7. Cromer B., (2013):

Adolescent Development. In: Kliegman RM, Behrman RE, Jenson HB, Stanton BF, eds. Nelson Textbook of Pediatrics. 19th ed. Philadelphia, Pa: Saunders Elsevier; 2013: chap 104.

8. Douglas K., (2011): "Sex Education: Access and Impact on Sexual Behaviour of Young 
Hayam A. EL-Refai et. al.

People," presented at the United Nations Expert Group Meeting on Adolescents, Youth and Development, New York, July 21-22, 2011, accessed at www.un.org/esa/population/me etings/ egmadolescents/p07_kirby.pdf, on Sept. 21, 2012.

9. Fahmy S, EL Sherbiny A. (1983): Determining Simple Parameters for Social Classification for Health Research. Bulletin of High Institute of Public Health 1983; 13 (5): 95-107.

10. Fields, J., \& Tolman, D. (2006): Risky business: Sexuality education and research in U.S. schools. Sexuality Research and Social Policy: Journal of NSRC, 3(4), 63-76.

11. Fonner V., Armstrong K., Kennedy C., O'Reilly K., Sweat M.., (2014): School based sex education and HIV prevention in low- and middleincome countries: a systematic review and meta-analysis, PLoS One. 2014 Mar 4;9(3):e89692. doi: 10.1371/journal.pone.0089692. eCollection 2014.date of access 9-2-2014

12. Forham, S., Sternberg, M., McQuillan, G., (2013):
Prevalence of Sexually Transmitted Infections Among Female Adolescents Aged 14 to 19 in the United States

13. Getahun $A$., (2014), Expert Evidence - the Impact of Moore v. Getahun, Reg. $438 / 08$, s. 48

14. Javadnoori, M., Roudsari, L., Hasanpour, M., Mohammad, S., Hazavehei, M., Taghipour, A., (2012): Female adolescents' experiences and perceptions regarding sexual health education in Iranian schools: A qualitative content analysis, Iranian Journal of Nursing and Midwifery Research November-December 2012 Vol. 17 | Issue 7

15. John B. Jemmott I., Loretta S. Jemmott, A. O'Leary, Z., (2014): Cluster-Randomized Controlled Trial of an HIV/Sexually Transmitted Infection Risk-Reduction Intervention for South African Men. American Journal of Public Health 104:3, 467-473. Online publication date: 1Mar-2014.

16. Kasiye S., Frehiwot G., and Getahun A. , (2014): Assessment of adolescents' communication on sexual and reproductive health matters with parents and associated 
factors among secondary and preparatory schools' students in Debremarkos town, North West Ethiopia, .Reproductive Health 2014, 11:2

17. Kirby D., Obasi A., Laris B., (2006): The effectiveness of sex education and HIV education interventions in schools in developing countries. World Health Organ Tech Rep Ser. 2006;938:10350; discussion 317-41.

18. Kuriansky, J. \& Schroeder, E. (2009): Sex education: Past, present, and future: Volume $1.1^{\text {st }}$ ed., Westport, CT: Praeger, USA., P.P. 120-122

19. Shweta, S., Mundkur, S., Chaitanya, V., (2011): Knowledge and Beliefs about HIV/AIDS among adolescents. webmedcentral paediatrics

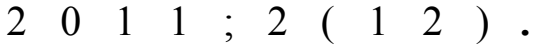

20. Lema L., Katapa R., Musa A., (2008): Knowledge on HIV/AIDS and sexual behaviour among youths in Kibaha District, Tanzania. Tanzan J Health Res. 2008 Apr;10(2):79-83.

21. Bearinger, L., Sieving, R., Ferguson, J., Sharma, V., (2007): Global perspectives on the sexual and reproductive health of adolescents: patterns, prevention, and potential, The Lancet, Volume 369, Issue
9567, 31 March-6 April 2007, Pages 1058-1060,

22. Mahan, T., Tryblski, J., Polgar, P., Sandberg, J., (2009): Primary Care: A Collaborative Practice, $4^{\text {rd. }}$ ed., Mosby Elsevier co., United State of America, p.p.40-41.

23. Martin, et al., (2009), Handbook of Adolescent Health Care, $1^{\text {st }}$ ed. Walters Kluwer Lippincott Williams\& Wilkins, USA, P.P. 357.

24. Myron, S., Cohen,A.,Marybeth M., and Theresa, R., (2012): HIV treatment as prevention and HPTN 052, Curr Opin HIV AIDS. 2012 Mar; 7(2): 99105.

25. National Child Traumatic Stress Network, (NCTSN) (2009), Sexual development and behavior in children: Information for parents and caregivers. (C) National Sexual Violence Resource Center 2013. The National Child Traumatic Stress Network. www.NCTSN.org

26. Oraby, D., (2013), Sexual and reproductive health among young people in Egypt: the role and contribution of youthfriendly services, Sex Education, 2013 Vol. 13, No. 4, 470-477, 
Hayam A. EL-Refai et. al.

\begin{tabular}{llllr}
\hline 27. Padhy, G., Pattanayak, A., & 32. & Russell, S. & T. & (2005b): \\
Jana, & Conceptualizing & positive \\
Effectiveness of Planned & adolescent & sexuality \\
Teaching Program (PTP) on & development. & Sexuality \\
Knowledge of Sex Education & Research \& Social Policy, \\
among Adolescent Girls. & $2(3), 4-12$. &
\end{tabular}

Indian J Pediatr.108(3), 278291

28. Patricia G., Eric R. Buhi,S., Dunsmore, M., (2006): Selfesteem and adolescent sexual behaviors, attitudes, and intentions: a systematic review, Journal of Adolescent Health, Volume 38, Issue 3, March 2006, Pages 310-319

29. Rahman M., Kabir M., Shahidullah M., (2009): Adolescent knowledge and awareness about AIDS/HIV and factors affecting them in Bangladesh. J Ayub Med Coll Abbottabad. 2009 JulSep;21(3):3-6.

30. Rathfisch G., Aydin M., Pehlivan M., Bozurt B., Kaplica I., ( 2012): Evaluation of reproductive health and sexual behaviors of university students: case study from Istanbul. Contemp Nurse. 2012 Dec;43(1):47-55.

31. Russell, S. T. (2005a). Introduction to positive perspectives on adolescent sexuality: Part I. Sexuality Research \& Social Policy, 2(3), 1-3.

33. Samkange-Zeeb, F., Spallek, L., Zeep, H., ( 2011): Awareness and knowledge of sexually transmitted diseases (STDs) among school-going adolescents in Europe: a systematic review of published literature, BMC Public Health 2011, 11:727

34. Sexuality Information and Education Council of the US (SIECUS)(2009): Guidelines for the Sexual Health Education Component of Comprehensive Health Education. Sexuality Education Q \& A. Retrieved on March 2, 2009, from http://Www.Siecus.Org/Index. Cfm?Fuseaction=Page. Viewpa ge \&Pageid $=521 \&$ Grandparenti $\mathrm{d}=477 \&$ Parentid=514). Date of acess 23-8-2013

35. Shedlin M., Amastae J., Potter J., Hopkins K., Grossman D., ( 2013): Knowledge and beliefs about reproductive anatomy and physiology among MexicanOrigin women in the USA: implications for effective oral contraceptive use. Cult Health Sex. 2013;15(4):466-79. 
36. Sionean C., Hageman, K., Oster, A., Wejnert, C., Hess, K., Paz-Bailey, G.; (2014): HIV Risk, prevention, and testing behaviors among heterosexuals at increased risk for HIV infection--National HIV Behavioral Surveillance System, 21 U.S. cities, 2010., MMWR Surveill Summ. 2014 Dec 19; 63(14):1-39.

37. Stephen D., Bryant W., Wilson D., ( 2008): Selfassessment of sexual maturation in children and adolescents with diabetes mellitus. Endocr Pract. 2008 Oct;14(7):840-5.

38. Theresa, R., (2012): HIV treatment as prevention and HPTN 052, Curr Opin HIV AIDS. 2012 Mar; 7(2): 99105.

39. Tolman, D. L., Hirschman, C., \& Impett, E. A. (2005). There is more to the story: The place of qualitative research on female adolescent sexuality in policy making. Sexuality Research \& Social Policy, 2(4), 4-17.

40. United Nations Population Division, (2013):

"Demographic Components of Future Population Growth". Technical Paper, 2013/3.

41. World Health Organization, (2006): library cataloguing. In publication data. Investing in our future: A Framework for Accelerating Action for The Sexual and Reproductive Health of The Young People: WHO: 2006.

42. WHO, (2013): International Conference on Population and Development, January 2015, Volume 56, Issue 1 , Supplement, S1-S60

43. Wong, K., Chan, W., Choi, Y., Fong, C., Lam, K., Sham, W., (2013): A cross-sectional study of the beliefs and attitudes towards menstruation of Chinese undergraduate males and females in Hong Kong. J Clin Nurs. 2013 Dec;22(23-24):3320-7.

44. Yin, L., et al., (2014): Sexual Risk Reduction for HIVInfected Persons: A MetaAnalytic Review of "Positive Prevention" Randomized Clinical Trials, PLoS One. 2014; 9(9): e107652.

45. Zajac K., Kennedy C., Fonner V., Armstrong K., O'Reilly K., Sweat M., (2014): A Systematic Review of the Effects of Behavioral Counseling on Sexual Risk Behaviors and HIV/STI Prevalence in Low- and Middle-Income Countries. PLoS One. 2014 Mar 4;9(3):e89692 